\title{
Gapienie się a prawo głosu. O przemianach obrazu niepełnosprawności we współczesnej polskiej literaturze dla dzieci
}

\begin{abstract}
Kwiatkowska Agnieszka, Gapienie się a prawo głosu. O przemianach obrazu niepełnosprawności we współczesnej polskiej literaturze dla dzieci [Staring vs. the right to speak. On changes in portraying disability in contemporary Polish literature for children]. „Przestrzenie Teorii” 34. Poznań 2020, Adam Mickiewicz University Press, pp. 325-344. ISSN 1644-6763. DOI 10.14746/pt.2020.34.15.

The article analyses the way in which disability is portrayed in contemporary Polish literature for children, with a particular emphasis on the latest literature. Rosemarie Garland-Thomson's theory of the baroque stare is applied in the analysis and allows the reconstruction of a network of stares in which the disabled are entangled, and also to reconstruct the place attributed to them in society. In a number of texts, a confrontation with onlookers turns out to be an introduction to a dialogue that gives a disabled person a chance to express their feelings and needs. However, the increasingly common portrayal of disability in the social category does not free literature from stereotypes.
\end{abstract}

KEYWORDS: staring, disability, literature for children, narrative prosthesis, body, different

Większa otwartość współczesnego świata, przyzwolenie społeczne na obecność osób z niepełnosprawnościami w przestrzeniach publicznych i coraz lepsze przystosowania architektoniczne sprawiły, że osoby o nienormatywnej motoryce można spotkać w sklepach, urzędach, kinach, teatrach, muzeach, na lotniskach i w środkach komunikacji miejskiej. Przemiany obserwowane $\mathrm{w}$ tej dziedzinie życia społecznego znajduja swoje odzwierciedlenie w literaturze dla dzieci, która coraz częściej podejmuje tematy związane z niepełnosprawnością i ukazuje bohaterów poruszających się nietypowo. Osoby z niepełnosprawnościami narządów ruchu w sposób szczególny przyciagaja wzrok przechodniów. Inny niż ogólnie przyjęty sposób poruszania się i nienormatywne ciało niepokoja, budzą zaciekawienie, a nawet fascynację swą odmiennością i naruszaja percepcyjne przyzwyczajenia. Sposób patrzenia na osoby z fizycznymi dysfunkcjami, wymiana spojrzeń poparta mimiką i mowa ciała budują model niewerbalnej komunikacji, który w pewnym stopniu określa miejsce osoby niepełnosprawnej i role, jakie wyznacza jej społeczeństwo.

Kontakt wzrokowy może być wyrazem ciekawości i początkiem partnerskiego dialogu, w rzeczywistości częściej jednak bywa wyrazem wiedzy i władzy ${ }^{1}$. Spojrzenia kategoryzuja obserwowanego przez pryzmat jego

${ }^{1}$ M. Foucault, Stowa i rzeczy. Archeologia nauk humanistycznych, Gdańsk 2006, s. 211. 
odmienności, uprzedmiotawiają i stanowią potwierdzenie istniejącego porządku, w którym osoby z niepełnosprawnościami zostały wyodrębnione ze społeczeństwa jako specyficzna grupa definiowana przez fizyczną nienormatywność. W tym przypadku wiedza rozumiana za Michaelem Foucaultem jako dochodzenie do prawdy i ujawnianie prawdy, sprowadzona zostaje do potwierdzania wstępnie przyjętych założeń dotyczących ograniczeń tej grupy społecznej, władza natomiast służy podtrzymaniu takiego porządku świata, w którym - jak pisał Pierre Bourdieu - porządek znaczeń wyznaczany jest przez dominujące warstwy i klasy społeczne ${ }^{2}$. Spojrzenia oceniające i uprzedmiotawiające, których nadawcy nie oczekują odpowiedzi, patrzą bowiem poznawczo zadziwieni innością i nie dążą do interpersonalnego dialogu, mają wymiar przemocy symbolicznej, klasyfikują bowiem wszystkich według odgórnie ustalonego porządku³.

Analiza wzrokowych interakcji - tego, kto i w jaki sposób przygląda się osobom z niepełnosprawnościami, z jaką reakcją się spotyka, jakie odczucia wywołuje - ukazanych w wybranych utworach literackich umożliwia zrekonstruowanie zawartego w nich obrazu niepełnosprawności, odkrycie jej ewentualnego wartościowania, ujawnienie stygmatyzacji związanej z uruchomieniem czysto medycznej perspektywy czy ukazanie przewartościowania zdeterminowanego wpisaniem dysfunkcji ruchowych w porządek różnorodności społecznej ${ }^{4}$. Związek między modelem wzrokowej komunikacji a specyfiką kulturowego modelu niepełnosprawności szczególnie wyraźnie widać w literaturze dla dzieci, kierowanej do odbiorców, którzy nie w pełni jeszcze przyswoili sobie społeczne nakazy i zakazy dotyczące przyglądania się drugiemu człowiekowi. Sieć spojrzeń, w która uwikłani są bohaterowie powieści Magdy Papuzińskiej, Ireny Landau, Katarzyny Zychli, komiksu Spella, opowiadań Katarzyny Lewandowskiej-Turzyńskiej i Moniki Drużyńskiej czy historyjek zebranych w tomie przygotowanym przez Agnieszkę Kossowska, odzwierciedla społeczne oczekiwania wobec niepełnosprawnych, wyznaczając im określone miejsce $\mathrm{w}$ świecie i determinując po części ich powinności ${ }^{5}$. W przypadku studiów nad niepełnosprawnością czytanie litera-

${ }^{2}$ M. Rzeszutko-Iwan, Kategorie wiedzy i władzy w dyskursie publicznym, „Acta Universitatis Lodziensis" 2014, 21, s. 24.

${ }^{3}$ P. Bourdieu, J.C. Passeron, Reprodukcja. Elementy teorii systemu nauczania, Warszawa 1990, s. 23.

${ }^{4}$ Temat niepełnosprawności jako zjawiska społecznego podejmowało wielu badaczy, m.in. Rosemarie Garland-Thomson i Lennard J. Davis. R. Garland-Thomson, Extraordinary Bodies: Figuring Physical Disability in American Culture and Literature, New York 2017. L.J. Davis, The End of Normal: Identity in a Biocultural Era, Michigan 2014.

${ }^{5}$ Przywoływać będę następujące utwory m.in. wymienionych w tym akapicie autorów i autorek: Monika Drużyńska, Jak oswoić potwory? Opowiadania terapeutyczne (2018); To- 
tury łączy się jednak z czytaniem świata - problemy rozważane w poszczególnych tekstach prowokują do zadawania niewygodnych pytań nie tylko dziełom literackim, ale również do analizowania stosunków społecznych. W literaturze rzeczywistość przegląda się jak w lustrze, odsłaniając dominujący porządek. Wiele tekstów literackich ukazuje świat w zaskakującej perspektywie, podważajac stereotypy, odrzucajac pozory ładu gwarantowanego przez Foucaultowską władzę. Niektóre też narzucają odbiorcy wypaczoną wizję niepełnosprawności i wpisują się w proces narzucania znaczeń, utrwalając skostniałe schematy i stanowiąc narzędzie symbolicznej przemocy. Napięcie, które można dostrzec w relacjach między tekstami jest w pewnym sensie odzwierciedleniem napięć możliwych do zaobserwowania w życiu społecznym, towarzyszących przemianie sposobu postrzegania osób z niepełnosprawnościami.

W analizie semantyki patrzenia wpisanej w wybrane utwory literackie niezwykle przydatna jest teoria Rosemarie Garland-Thomson poświęcona gapieniu się rozumianemu m.in. jako reakcja na zniewalajacy charakter tego, co widzimy ${ }^{6}$. Fascynacja niesamowitością sprawia, że patrzenie przekracza czasem ramy akceptowalnej uważności i wywołuje emocje pozostajace poza kontrola rozumu. Barokowe gapienie się - jak nazywa badaczka ten szczególny rodzaj obserwacji - wyrasta przede wszystkim z zadziwienia nierozerwalnie połaczonego z chęcia poznania. Równocześnie jednak ma charakter uprzedmiotawiajacy, celem jego nie jest bowiem empatia wobec Innego, ale raczej kontemplacja dziwu postrzeganego w sposób absolutnie rzeczowy. Jakakolwiek reakcja (czy choćby potencjalna możliwość reakcji) ze strony osoby, która przyciaga spojrzenia innych, nadaje jednak gapieniu się wymiar szczególnego spotkania, które redefiniuje obie strony interakcji. Zderzenie to interpretować można zarówno w literaturoznawczej, jak i socjologicznej perspektywie. Sposób patrzenia, który nie zakłada naruszenia

masz „Spell” Grządziela, Przygody Stasia i Złej Nogi (2016); Agnieszka Kossowska, Duże sprawy w małych głowach (2016); Irena Landau, Uszy do góry (2011); Katarzyna Lewandowska-Turzyńska, Kompleksy pandy i niepetnosprawność żyrafki (2017); Magda Papuzińska, Wszystko jest możliwe (2003); Jadwiga Ruth-Charlewska, Dziewczynka spoza szyby (1964) oraz (jako kontekst z zakresu literatury dla młodszej młodzieży): Krystyna Boglar, Stonoga (1984); Ewa Nowak, Lawenda w chodakach (2004); Seweryna Szmaglewska, Nowy ślad Czarnych Stóp (1973); Katarzyna Zychla, Dziewczynka tańczqca z wiatrem (2007). Lokalizacja cytatów sygnowana jest w tekście głównym - w nawiasie przywołuję incipit tytułu i podaję numer cytowanej strony.

${ }^{6}$ R. Garland-Thomson, Staring. How we look, New York 2009. Fragmenty w przekładzie Katarzyny Ojrzyńskiej ukazały się na łamach „Czasu Kultury” 2019, 4, s. 73-81. Problematyka gapienia się jest też szeroko podejmowana w obrębie projektu „Gap się!”, realizowanego przez Fundację Teatr 21. W ramach projektu przygotowywany jest m.in. przekład książek R. Garland-Thomson, Extraordinary Bodies... i Staring... 
dotychczasowego ładu, przypisany wówczas zostaje wiedzy i władzy oraz powiązany z ewokowaniem symbolicznej przemocy. Podważenie istniejącego porządku i poliwalentyzacja narzucanych znaczeń pozwalają natomiast na rozpoczęcie dialogu prowadzącego do autentycznego poznania i dowartościowania różnorodności. Wykorzystanie prac Michaela Foucaulta i Pierre'a Bourdieu pozwoli więc odnieść ustalenia Rosemarie Garland-Thomson nie tylko do literatury, ale i do rzeczywistości zewnątrztekstowej i przyjrzeć się relacji łączącej te dwa nieodległe światy.

Czy w najnowszych książkach dla dzieci bohaterowie o niezwykłych ciałach $^{7}$ przyciagają spojrzenia innych? W jaki sposób spoglądają na nich bliscy i całkiem obcy ludzie? Co budzi nieprzepartą chęć obserwacji i jakie konsekwencje niesie niepohamowane gapienie się? Czy literackie reprezentacje tego zjawiska mają dziś inny charakter niż $\mathrm{w}$ minionych dekadach? Czy sposób patrzenia na osoby z niepełnosprawnościami ewoluuje tak samo w życiu, jak i w literaturze, stopniowo uwalniając się od narzuconych przez stereotypy osądów? Tak ukierunkowana lektura wybranych utworów pozwoli zrekonstruować sposób przedstawiania niepełnosprawności w najnowszej literaturze dla dzieci, odsłonić wpisane w dany utwór postawy i ujawnić kierunki dydaktycznego oddziaływania. Badania dotyczące niepełnosprawności w literaturze dla dzieci były już wielokrotnie podejmowane, m.in. przez Krystynę Zabawę, Annę Fidowicz i Anitę Wolanin ${ }^{8}$. W większości prac, zgodnie z założeniami disability studies, nie wyodrębnia się poszczególnych dysfunkcji, traktując niepełnosprawność ruchowa, sensoryczną czy intelektualną jako różne rodzaje odmienności budującej społeczne zróżnicowanie. Tym jednak, co przykuwa spojrzenia, jest nienormatywne ciało i jego oryginalna mobilność. To właśnie połączenie odmienności kształtu oraz niezwykłego sposobu poruszania się bądź niepokojącego bezruchu stanowi nieodpartą pokusę dla gapiów, stwarzając odrębna kategorię interpretacyjną. Bohaterowie poruszający się na wózkach inwalidzkich, chodzacy o kulach, korzystający z ortez, ortopedycznych gorsetów czy balkoników patrzą i są oglądani w sposób głęboko znaczący, wymagający wielowarstwowych odczytań.

\footnotetext{
${ }^{7}$ Określenie „niezwykłe ciała” odsyła do tytułu książki R. Garland-Thomson, Extraordinary Bodies...

${ }^{8} \mathrm{~K}$. Zabawa, Ryzyko spotkania z innym - niepetnosprawny we wspótczesnej literaturze dla dzieci, [w:] Edukacja polonistyczna wobec Innego, red. A. Janus-Sitarz, Kraków 2014, s. 121-142; A. Fidowicz, Niepetnosprawność w Polskiej literaturze dla dzieci XIX wieku, „Wielogłos” 2006, 4, s. 11-126; A. Wolanin, Odmieniec i jego postawy wobec świata w twórczości Doroty Terakowskiej, [w:] Wyczytać świat - międzykulturowość w literaturze dla dzieci i młodzieży, red. B. Niesporek-Szamburska, M. Wójcik-Dudek, Katowice 2014, s. 175-183.
} 


\section{Wobec spojrzenia władzy}

Bohaterowie powieści Magdy Papuzińskiej Wszystko jest możliwe i Ireny Landau Uszy do góry potrafią przeciwstawić się narzuconemu porządkowi, odrzucić etykietki i zyskać wewnętrzną wolność, uniezależniając się od symbolicznej przemocy, choć na pozór niewiele od nich samych zależy. Żółwik, główny bohater powieści Magdy Papuzińskiej, czuje się obiektem nie tylko spojrzeń, ale przede wszystkim różnych działań - jest karmiony, kapany, wyprowadzany na spacer. Myśli: „większość czasowników mogę stosować do siebie tylko w stronie biernej" (Wszystko..., s. 5). Często staje się też przedmiotem obserwacji, ciekawskiego gapienia się, które jednak prawie nigdy nie generuje kontaktu. Chłopiec doskonale zdaje sobie sprawę z zachodzącego w tym przypadku procesu uprzedmiotowienia i w myślach tak go komentuje:

Czasem, kiedy siedzę tak jak teraz na moim wózku przed blokiem w słoneczne upalne popołudnie i patrzę na przechodzących ludzi, zmęczonych po pracy, to żal mi ich. Tak rzadko się uśmiechaja, chociaż przecież mogą się uśmiechać. Ja, gdybym mógł, to śmiałbym się bez przerwy na głos. Teraz też się śmieję, ale nikt tego nie widzi, więc nikt nie odwzajemnia mojego uśmiechu. Przechodzą obok mnie i spuszczają głowy albo patrzą w drugą stronę, jakby nie chcieli mnie widzieć. A przecież mnie widzą. Codziennie od tylu lat. Trochę szkoda, bo lubię patrzeć na uśmiechniętych ludzi. Czasami, kiedy im się wydaje, że nie patrzę, bo mam przymknięte oczy - ale ja patrzę - przyglądaja mi się ciekawie. Patrzą nie jak na człowieka, ale na zadziwiający obiekt, który żyje, chociaż nie powinien (Wszystko..., s. 9).

Właśnie tego rodzaju spojrzenia Rosemarie Garland-Thomson kwalifikuje jako barokowe gapienie się, tak charakteryzując jego specyfikę:

Naglące pytanie: „Co to jest?” podnieca barokowych gapiów. Tego rodzaju wizualna dociekliwość sprawia, że osoba, na którą skierowany jest wzrok gapia, jawi się jako nieczytelna. Osoba taka, uznana za obcego, jest jednocześnie przypierana do muru i upodmiotawiana. W końcu to jej widok rzucił gapia na kognitywne kolana. Barokowe gapienie się uwidacznia w ten oto sposób uczestników zaistniałej interakcji ${ }^{9}$.

Co ciekawe, bolesne doświadczanie cudzych spojrzeń i nieprzyjemne odczucie przyparcia do muru zupełnie zanika, gdy Jaś-Żółwik czuje się szczęśliwy i spełniony. W finałowej scenie powieści, gdy rozkoszuje się pobytem nad morzem, przez kilka chwil leży „nagą skórą dotykając piasku” (Wszystko..., s. 87) i pod czujna opieką brata pływa na dmuchanym materacu, nikt się na niego nie gapi, choć na plaży „wylegują się tłumy golasów” (Wszystko..., s. 87). Czy rzeczywiście każdy z plażowiczów do tego stopnia

${ }^{9}$ R. Garland-Thomson, Gapienie się, czyli o tym, jak patrzymy i jak pokazujemy siebie innym, przeł. K. Ojrzyńska, „Czas Kultury” 2019, nr 4, s. 74. 
zajęty jest swoimi sprawami, że nietypowe ciało Jasia nie zwraca niczyjej uwagi? Bardzo wątpliwe. To raczej główny bohater, któremu każdy dzień przynosi „jedno malutkie spełnione marzenie więcej”, wyszedł z roli niepełnosprawnego i nie podejmuje już społecznej gry z gapiami. Otoczony jest znajomymi, dla których przestał być obcym, a jego cielesność nie stanowi już „dziwu” generującego żądzę poznania ${ }^{10}$. W końcowych partiach utworu wzrok Jasia nie sięga poza ten bezpieczny krag i w pewnym sensie nie docierają też do niego spojrzenia innych ludzi. Moc barokowego gapienia się, wcześniej karmiona próżnią otaczającą Jasia niemal zupełnie pozbawionego międzyludzkich kontaktów, osłabła, ustępując miejsca pełnoprawnym relacjom i związanym z nimi emocjom.

Narzędziem symbolicznej przemocy może być nie tylko spojrzenie, ale i jego brak, omijanie wzrokiem Innego, który - uprzedmiotowiony - jest tylko elementem zakłócającym harmonię przestrzeni. Ojciec Jasia - przedstawiciel kultury patriarchalnej - woli na syna nie patrzeć, ignoruje go i chętnie zapomniałby o jego istnieniu. Renata - kuzynka i dawna przyjaciółka Majki z powieści Ireny Landau Uszy do góry - wolałaby w ogóle nie widzieć osób z niepełnosprawnościami. Na wycieczce do Ciechocinka obie dziewczynki współczuły osobom poruszającym się na wózkach inwalidzkich, ale w Renacie budziły one niemal wstręt.

Owszem, żałowały ich obie, ale Renia nie lubiła na nich patrzeć, po prostu wszystko się w niej przewracało, kiedy widziała tych kompletnie przegranych i biednych ludzi. [...] Raz, kiedy wyszły same, jeden dorosły chłopak na wózku spytał ja, którędy idzie się do Truskawki. Renata niby wiedziała, gdzie jest to sanatorium, ale nie miała ochoty na rozmowy. Ten chłopak nogi miał dziwnie powykręcane i zgięte i Reni po prostu robiło się niedobrze. Nie mogła sobie wyobrazić takiego życia, co ten nieszczęsny kaleka mógł ze sobą zrobić? Ani biegać, ani gdzieś iść, niewola i zmarnowane życie (Uszy..., s. 14).

Nic dziwnego, że Renia nie chce na czas wyjazdu rodziców zamieszkać u wujostwa, gdzie dzieliłaby pokój z niepełnosprawną kuzynką i musiałaby „codziennie patrzeć na taki horror”, a może nawet pomagać w opiece i „na przykład dotykać sparaliżowanych nóg" (Uszy..., s. 15). Renata zupełnie nie ma poczucia, że kuzynka po wypadku pozostała tą samą co niegdyś osobą i nie potrafi wyobrazić sobie wspólnego spędzania czasu. Dysfunkcyjne ciało - tak różne od jej własnego, a równocześnie tak przecież podobne - budzi

${ }^{10}$ R. Garland-Thomson pisze: „[...] wonder jako rzeczownik oznacza dziw, na którym spoczywa wzrok, natomiast jako czasownik - samą czynność podziwiania, czyli patrzenia na to, co dziwne. Dziwić się to pragnąć wiedzy. Dziwy są natomiast jej źródłem. Barokowe gapienie się jest zatem czymś więcej niż zainteresowanym patrzeniem. Porywający widok prowokuje barokowe spojrzenia nawet w czasach współczesnych. Innymi słowy - wciąż podziwiamy różne dziwy”. (R. Garland-Thomson, Gapienie się..., s. 74). 
irracjonalny lęk. Majka nie jest jednak drugoplanowa bohaterka, która mogłaby stać się przyczyną duchowej przemiany Renatki ${ }^{11}$. To postać wielowymiarowa, charakteryzowana nie tylko przez niepełnosprawność, która wpisuje się w codzienność dziewczynki wypełniona rozmowami z przyjaciółkami, fascynacją nowo poznanym chłopakiem, troską o szkolne stopnie, opieką nad małym kotkiem, organizacją wakacyjnego wyjazdu czy wreszcie rozszyfrowaniem źródła tajemniczych jęków niepokojących sąsiadkę. Przeszkody, z którymi musi zmierzyć się Majka, wynikają raczej ze stereotypów zakorzenionych w ludzkiej mentalności czy nieprzystosowania przestrzeni publicznej, a nie sa generowane bezpośrednio jej stanem zdrowia czy przyczynami natury medycznej. Doskonale ujmuje to ojciec głównej bohaterki, odpowiadając na bezceremonialne ubolewanie jednej z sasiadek. Mówi: „Nie może chodzić, a pani nie może fruwać [...] i jakoś pani żyje” (Uszy..., s. 44). W ten sposób sprowadza niepełnosprawność do kategorii stanowionej przez normę społeczna, przypisująca gatunkowi ludzkiemu określone umiejętności i niepozostawiająca marginesu na różnorodność. Ostatecznie dziewczynka będzie umiała stawić opór w obronie własnej tożsamości i nie pozwoli, aby postrzegano ją wyłącznie przez pryzmat ograniczeń w poruszaniu się. Podobnie jak Żółwik udowadnia, że analizowany przez Bourdieu habitus nie jest ostatecznie zdeterminowany ${ }^{12}$ i przy odrobinie sprzyjających okoliczności można uruchomić te jego dyspozycje, które dają wsparcie, pozwalają budować samoocenę, opierając się na wybranych relacjach, które dają wsparcie i sprawiaja, że wzrok gapiów najpierw zostaje unieważniony szeregiem spojrzeń przyjaznych, aby ostatecznie nabrać przyjacielskiego wymiaru. Przełożona na język dziecięcych pojęć społeczna teoria różnorodności, według której niepełnosprawność jest tylko jedną z cech osoby ludzkiej, definiowanej przez szereg elementów, tkwiącej - podobnie jak wszyscy - pomiędzy wieloma możliwościami i ograniczeniami ${ }^{13}$, przeciwstawia się narzuconym porządkom i w pewnym stopniu znosi przemoc symboliczna. Oboje bohaterowie dokonują czegoś w rodzaju mentalnego cripteasu $^{14}$ - dają sobie prawo

${ }^{11}$ Wyznaczniki gatunku zwanego „second fiddle” books, w którym osoba z niepełnosprawnością pełni rolę katalizatora przemian innych bohaterów, omówił L. Keith, What Writes Did Next: Disability, Illness and Cure in Books in the Second Half of the $20^{\text {th }}$ Century, „Disability Studies Quarterly" 2004, vol. 24, no. 1, <https://dsq-sds.org/article/view/845/1020> [dostęp: 10.06.2020]. Krystyna Zabawa nazywa ten model pisania o niepełnosprawności „literatura akompaniamentu" (K. Zabawa, Ryzyko..., s. 126).

${ }^{12}$ P. Bourdieu, L. Wacquant, Zaproszenie do socjologii refleksyjnej, przeł. A. Sawisz, Warszawa 2001, s. 122.

${ }^{13}$ R. Garland-Thomson, Niezwykte ciała, przeł. N. Pamuła, „Dialog” 2019, nr 7-8, s. 752.

${ }^{14}$ Termin cripteas (powstały z połączenia określenia kaleki criple i słowa striptease) stosowany jest w literaturze przedmiotu na określenie wyzwolicielskiego rozbierania się z protez, jakiego dokonał na scenie m.in. Wiles Fraser, rezygnując z oprotezowania, które nadawało 
do istnienia $\mathrm{w}$ świecie niedostosowanym do ich potrzeb, odrzucając myśl o własnym niedopasowaniu jako opresyjną i wpisaną w porządek władzy.

Narracja pierwszoosobowa, która została zastosowana w obu przywołanych utworach, podnosi wiarygodność i przydaje autentyczności opisywanym zdarzeniom. Chwyt artystyczny daje złudzenie, że niepełnosprawni mówią sami o sobie, wypracowując nowy model emancypacyjnej mowy wykluczonych $^{15}$. Jest to szczególnie wyraziste w powieści Papuzińskiej, gdzie narrator i główny bohater nie może porozumiewać się ze swoim otoczeniem. Odbiorca wewnętrznego monologu Jasia jest więc w sytuacji uprzywilejowanej, poznaje bowiem przemyślenia i refleksje, o których sparaliżowany chłopiec nie może opowiedzieć swoim bliskim. Aby przemówić, trzeba bowiem mieć głos - fizyczną możliwość komunikowania, odbiorców zainteresowanych opowieścią oraz kompetencje, które pozwolą na zbudowanie wypowiedzi. Niepełnosprawność ruchowa tylko w skrajnych przypadkach ogranicza możliwości komunikacji $\mathrm{w}$ sensie fizycznym. Często jednak decyduje o izolacji i wykluczeniu z grona rówieśników, redukując szansę na wyćwiczenie społecznych umiejętności.

\section{Spojrzenie jako przemoc symboliczna}

Świat uporządkowany jest tak, że przekonuje osoby z niepełnosprawnościami o ich odmienności, niedopasowaniu i ograniczeniach. Wygodny dla większości sposób organizowania przestrzeni czy przyjęty porządek architektoniczny nierzadko wykluczają mniej uprzywilejowanych, spychając ich na margines życia i uniemożliwiając budowanie pozytywnego obrazu samego siebie czy rozwijanie kompetencji społecznych. Obnażenie tego mechanizmu jest jednym z zadań literatury o podwójnym przesłaniu - dziecięcemu odbiorcy ukazującej bohatera, który pozostaje w opresji, dorosłym proponującej szyderczą krytykę opresyjnych mechanizmów rządzących światem i generujących nie tylko symboliczną przemoc.

W komiksie Spella Przygody Stasia i Złej Nogi główny bohater mówi raczej niewiele, nie potrafi opowiedzieć o swoich emocjach nawet w ga-

mu „normalny” wygląd, ale pozbawiało sprawności i swobodnego funkcjonowania. Magdalena Zdrodowska pisze: „Ciało artysty uwolnione od protez zdolne jest nie tylko do swobodnego funkcjonowania (przemieszczania się, ubrania czy rozebrania), jest też wygimnastykowane i atletyczne, a przez kontekst i konwencję, w jakiej pojawia się Fraser, podkreśla, że ciało, które z dumą ukazuje, jest także seksualne, może budzić pożądanie. M. Zdrodowska, Odrzucenie protezy: performens, polityka, tożsamość, „Czas Kultury” 2019, nr 4, s. 71.

${ }^{15}$ M. Świerkosz, Stwarzanie niepetnosprawnego ciała. Kilka uwag o performatywnej teorii i praktykach teatralnych, „Czas Kultury” 2019, nr 4, s. 17. Świerkosz odwołuje się tu do pracy R. Garland-Thomson, The Story of My Work: How I Became Disabled, „Disability Studies Quarterly” 2014, vol. 34, no. 2. 
binecie psychologa, a w rozmowach z mamą posługuje się zwięzłymi, dosłownymi komunikatami. Narracja personalna - zachowujacca prostotę i dobitność Stasiowej składni - sprawia jednak, że poznajemy świat $\mathrm{z}$ punktu widzenia niepełnosprawnego chłopca ${ }^{16}$. Pozornie pozbawiona emocji relacja, prowadzona $\mathrm{z}$ naiwnej perspektywy ma charakter demaskatorski i stanowi oskarżenie przeciwko obowiązującym mechanizmom społecznym. Tytułowa Zła Noga - przyczyna Stasiowej niepełnosprawności - zyskuje rangę odrębnej bohaterki tekstu, podejmuje własne decyzje, wchodzi w interakcje z innymi ludźmi, równocześnie stając się metonimią wszystkiego, co utrudnia chłopcu normalne funkcjonowanie. Wyodrębnienie Złej Nogi jako osobnej postaci pozwala Stasiowi zdystansować się wobec własnej niepełnosprawności. Rozdział Dokuczanki doskonale ilustruje ten mechanizm:

Zła Noga nie ma za dużo kolegów w szkole. Inne dzieci się z niej śmieją. A Zła Noga łatwo się denerwuje. I nie lubi, jak się ją przezywa. Dlatego nikt nie chce z nia siedzieć w ławce. Więc Staś zawsze siada obok Złej Nogi, żeby jej nie było smutno $\left(\right.$ Przygody..., s. 14) ${ }^{17}$.

Komizm tej opowieści podszyty jest dość smutną refleksją dotycząca praw rządzących światem, które skazują Stasia na samotność, nieprzystosowanie, wpędzaja go w szkolne kłopoty i doprowadzają do wyładowania nagromadzonych emocji przez agresję. Kiedy pewnego dnia Marceli przychodzi do szkoły z nogą w gipsie, wydaje się, że Staś wreszcie zyska kolegęchłopcy siedzą razem w ławce i spotykają się po szkole.

Rodzice Marcelego mówią, że Marceli musi bawić się z innymi dziećmi pomimo złamanej nogi. Inaczej wpadnie w depresję. Marceli i Staś nie wiedza, co to depresja. Ale Staś ma jej pewnie mnóstwo. Bo Marceli to pierwszy kolega, który go odwiedził (Przygody..., s. 29).

Komiksowy narrator niczego nie komentuje, nie wyjaśnia, nie głosi haseł tolerancji, akceptacji, równości czy poszanowania różnorodności - opisuje świat na miarę dziecięcej percepcji, bardziej dociekliwym czytelnikom oferując ironiczny przekaz implikowany, krytyczny wobec społeczeństwa i jego zasad. Tak naprawdę to nie Zła Noga czyni Stasia niepełnosprawnym - do jego wyalienowania doprowadza brak profesjonalnego wparcia w zakresie rehabilitacji i terapii psychologicznej (rozmowy ze szkolną psycholożką sa karykatura tego rodzaju pomocy), złe funkcjonowanie edukacji włączającej (Staś nie ma szans, aby nadrobić

${ }^{16}$ Forma komiksu stoi w opozycji do literatury wysokiej, która - jak zwraca uwage R. Garland-Thomson - przyczyniła się do stygmatyzacji Innego. R. Garland-Thomson, Extraordinary Bodies..., s. 30-32.

${ }^{17}$ Przywołuję tu tylko tekst, który towarzyszy komiksowym ilustracjom. 
braki wywołane nie najlepsza, spowodowana choroba, frekwencja $)^{18}$ oraz kłopoty finansowe, jakich doświadcza samotna matka opiekująca się niepełnosprawnym dzieckiem.

Nie wiemy, co dolega Stasiowi, jego przypadek nie został w obrębie komiksu medycznie zdiagnozowany. Możemy natomiast obserwować, jak mechanizm funkcjonowania społeczeństwa z wolna obraca się przeciwko niemu, choć pozornie wszyscy bardzo się starają i mają mnóstwo dobrej woli. Pełną świadomość sytuacji ma tylko mama Stasia, która dosadnie diagnozuje szkolne sytuacje, ale pozostaje wobec nich całkowicie bezradna. Może tylko zapewniać Stasia, że nie jest „inny niż reszta dzieci”, albowiem „wszyscy ludzie są wyjątkowi”, a on ,jest bardziej wyjątkowy od innych dzieci" (Przygody..., s. 23). Rozpaczliwe przekonanie o słuszności idei różnorodności społecznej to jednak za mało, aby zbudować szczęśliwe i harmonijne życie. Mimo wszystko Staś nie przyjmuje roli ofiary, choć wszyscy wokół radzi by mu taką formę narzucić. Gdy ludzie się mu przyglądaja, on też patrzy na nich, powodując, że szybko odwracają wzrok. Chłopiec cieszy się, że jest „mistrzem pojedynkowania się na spojrzenia” (Przygody..., s. 6), ale głębszy wymiar tej sytuacji nie pozostawia żadnych wątpliwości - główny bohater spoglądając w twarz innym, nie pozwala się uprzedmiotowić, co wytrąca gapiów z równowagi i zaburza proces kontemplowania dziwu ${ }^{19}$. Niepełnosprawny od urodzenia Staś - na pozór niezdolny do głębszej autorefleksji - wie, kim jest i nie ma kłopotu z rozpoznaniem własnej tożsamości. Nie musi gapić się w lustro ${ }^{20}$ ani kontemplować inności swego ciała, aby poznać i uspójnić własną osobę, autoidentyfikacją obejmując także Złą Nogę - integralny element jego egzystencji. Kiedy pewnego dnia mama opowiada sen, w którym Staś był całkowicie sprawny, chłopiec protestuje: „Ale jak to. Bez Złej Nogi? Przecież bez Złej Nogi Staś nie byłby Stasiem” (Przygody..., s. 74). Główny bohater postrzega jednak swoją niepełnosprawność nie tylko jako źródło ograniczeń, ale też integralny element własnej tożsamości. Zadziwiony, marzenie matki odrzuca jako opresyjne i absurdalne. Matka Stasia akceptuje chłopca bez zastrzeżeń, ale sama pozostaje ofiarą systemu, narzucającego nieosiagalne dla niej standardy. Ona również - ekscentryczna, wiecznie poirytowana, z nieodłącznym papierosem w dłoni - przywołuje oceniające spojrzenia gapiów, którzy taksują jej macierzyńskie kompetencje i opiekuńczą sprawność.

${ }^{18}$ P. Bourdieu wskazał szkołę jako jedną z podstawowych instytucji będacych narzędziem przemocy symbolicznej.

${ }^{19}$ R. Garland-Thomson, Gapienie się..., s. 74.

${ }^{20}$ Tamże, s. $74-76$. 


\section{Spojrzenie w lustro}

Bohaterowie o niepełnosprawności nabytej częściej gapią się na siebie samych, przyglądają się swemu odbiciu w lustrze, w okiennej czy wystawowej szybie, doświadczając poczucia odrębności i obcości. Z jednej strony odkrywają wówczas, jak ich widza inni, z drugiej - lustrzanemu odbiciu przeciwstawiają dawny obraz przywołany z pamięci i integralnie powiązany $\mathrm{z}$ konstrukcją tożsamości ${ }^{21}$. Takie doświadczenie jest udziałem dziewczynki tańczacej z wiatrem - tytułowej bohaterki powieści Katarzyny Zychli:

Patrzyła w lustro i nie poznawała samej siebie. Krótkie włosy, smutne oczy, blizny po szwach. Była dla siebie obca osoba. Kimś z innej planety. Tamta Aleksandra miała długie, piękne jasne włosy i oczy, które niemal zawsze się śmiały (Dziewczynka..., s. 21).

Osoba w lustrze - zwraca uwagę Rosemarie Garland-Thomson - nie jest osoba, której doświadczamy. Świadomość własnego ciała oparta jest raczej na doświadczeniu dotyku, somatycznego kontaktu z otoczeniem, a percepcja wzrokowa stanowi tylko rekonstrukcję cudzych spojrzeń. „Rozdźwięk pomiędzy widzeniem siebie a byciem sobą"22 wyzwala autorefleksję i staje się zaczątkiem autoanalizy. Aleksandra z powieści Zychli daleka jest od narcystycznych afirmacji, ale z wolna odkrywa integralność swojej tożsamości, która - mimo wypadku i jego konsekwencji - pozostała niezmieniona.

Narracja w powieści Zychli jest trzecioosobowa, ale wiarygodności przydają jej fotografie, które sugeruja, że przywołana historia oparta jest na faktach, choć nie wspomniano o tym we wstępie czy posłowiu. Główna bohaterka znajduje pokrzepienie w autobiograficznej książce Joni Eareckson Tada, co dodatkowo dowartościowuje gatunek disability life writing ${ }^{23}$. Popularność tego rodzaju prawdziwych historii koresponduje z postulatami aktywistów z kręgu disability studies, którzy niejednokrotnie upominali się o oddanie głosu osobom z niepełnosprawnościa, wskazując na wartość osobistych doświadczeń przełożonych na literaturę. Książki oparte na autentycznych doświadczeniach, sytuujące się na pograniczu literatury pięknej, biografii czy autobiografii, reportażu i literatury faktu, cieszą się popularnością dzię-

${ }^{21} \mathrm{O}$ budowaniu tożsamości osoby niepełnosprawnej pisała Rosemarie Garland-Thomson w artykule Becoming Disabled, „The New York Times”, 19.08.2016, <https://www.nytimes. com/2016/08/21/opinion/sunday/becoming-disabled.html> [dostęp 10.06.2020].

${ }^{22}$ R. Garland-Thomson, Gapienie się..., s. 75.

${ }^{23} \mathrm{O}$ popularności gatunku zwanego disability life writing pisały m.in. K. Ojrzyńska, N. Pamuła, Nowe studia o niepetnosprawności w humanistyce, „Przegląd Kulturoznawczy” 2019, nr 3 (41), s. 379. 
ki umiejętnemu połączeniu postawy świadectwa i wyznania ${ }^{24}$, co pozwala ukazać heroizm codzienności wzbudzający emocje czytelnika. W obrębie literatury dla dzieci wskazać można niewiele pozycji tego rodzaju, gdyż specyfika gatunku wymaga wysokiego poziomu samoświadomości głównego bohatera. W nieco inny sposób głos dzieciom z różnymi rodzajami niepełnosprawności oddała w swojej książce Agnieszka Kossowska, prezentując zbiór poruszających historii przedstawiających specyfikę autyzmu, niepełnosprawności ruchowej, sensorycznej, intelektualnej, powikłań związanych z wcześniactwem i epilepsja ${ }^{25}$. Formuła, w której rówieśnicy pomagaja swoim koleżankom i kolegom zrozumieć cudzą odrębność i różnorodność zdecydowanie odrzuca postawę lamentacyjna, wpisuje się w model lektury reparacyjnej zaproponowany przez Evę Kosofsky Sedgwick i realizuje postulaty Helen Aveling - badaczki, która niejednokrotnie wskazywała na konieczność przedstawiania sytuacji osób z niepełnosprawnością z ich perspektywy ${ }^{26}$.

„Odmienność [...] jest [...] tylko projekcją wyobrażeń zdrowych ludzi” pisze Kossowska we wstępie, upominając się o „świat bardziej tolerancyjny, pełen zrozumienia i współodczuwania" (Duże..., s. 6) ${ }^{27}$. Akceptacja i tolerancja to kluczowe słowa w terapeutycznych opowiadaniach, które maja przygotować dzieci zdrowe na kontakt z niepełnosprawnymi rówieśnikami. Osoby z dysfunkcjami - książka Kossowskiej jest w tej kwestii wyjątkiem zazwyczaj ukazywane są w nich dość stereotypowo, jako wymagające pomocy i pocieszenia. W opowiadaniu Katarzyny Lewandowskiej-Turzyńskiej Kompleksy pandy i niepetnosprawność żyrafki niepełnosprawność to przede wszystkim odmienność, która utrudnia nawiązywanie relacji z rówieśnikami. Nadwaga małej pandy i niepełnosprawność jej klasowej koleżanki nie wpisują się w społeczną różnorodność, ale ukazane zostały jako odstępstwo od normy, które trzeba zaakceptować, aby odnaleźć szczęście.

${ }^{24}$ M. Czermińska, Autobiograficzny trójkat: świadectwo, wyznanie i wyzwanie, Kraków 2014, s. 23.

${ }^{25}$ Rozdział dotyczący wcześniactwa i epilepsji dodano w drugim wydaniu książki (2016).

${ }^{26}$ M. Świerkosz, Stwarzanie..., s. 17. Świerkosz odwołuje się tu do pracy R. Garland-Thomson, The Story of My Work... Oddziaływanie książek pisanych przez niepełnosprawnych autorów na literaturę dziecięcą badał też L. Keith, What Writes Did Next..., oraz H.A. Aveling, Modelling Illness in the Early $20^{\text {th }}$ Century, [w:] Unseen Childhoods Disabled Characters in $20^{\text {th }}$-century Books for Girls, red. H.A. Aveling, London 2009, e-book, loc. 327.

${ }^{27}$ Książka Kossowskiej należy do gatunku „problem” books, w którym kreacja bohaterów i fabuła utworu podporządkowane są wyjaśnieniu specyfiki danej niepełnosprawności czy choroby i kształtowaniu właściwych postaw wobec dotkniętych nimi dzieci. P. Thomson, Disability in Modern Children's Fiction, „Books for Keeps” 1992, no. 75, <http://booksforkeeps. co.uk/printpdf/issue/75/childrens-books/articles/other-articles/disability-in-modern-childrens-fiction> [dostęp: 9.06.2020]; K. Zabawa, Ryzyko..., s. 127. 
Dość płytko temat niepełnosprawności traktuje też opowiadanie $\mathrm{Na}$ pozór ktoś inny, czyli niezwykła Magi i jej wózek z książki Moniki Drużyńskiej Oswoić potwory. Scenki, które mają uczyć, jak traktować osoby z niepełnosprawnościa, nie pozostawiają odbiorcy przestrzeni na własne przemyślenia, a abstrakcyjne i oderwane od rzeczywistości frazesy z trudem trafiają do najmłodszych odbiorców. Mama Nikoliny, która właśnie poznała niepełnosprawną Magi, poucza swoją córeczkę: „Kiedy poznajesz kogoś niepełnosprawnego, nie okazuj wobec niego wyższości ani litości. [...] Po prostu traktuj ją normalnie" (Jak oswoić..., s. 56). Dorosła bohaterka opowiadania najwyraźniej zakłada, że poczucie wyższości i litość to naturalne reakcje w obliczu niepełnosprawności, dobre wychowanie nakazuje jednak powstrzymać się przed ich uzewnętrznieniem. Taka też jest wymowa całego opowiadania, w którym w finałowej scenie zaprzyjaźnione dziewczynki planują ozdobić wózek Magi „klamerkami i kokardkami, żeby nie był taki smutny" (Jak oswoić..., s. 59). Autorki przywołanych opowiadań postuluja pełną integrację i przedstawiają afirmatywnie zróżnicowane, harmonijnie funkcjonujące społeczeństwo. Równocześnie jednak ukazują niepełnosprawność jako stygmatyzującą dysfunkcję, co postulatom inkluzywności nadaje odcień hipokryzji, jak gdyby wynikały z zasad kindersztuby, a nie z autentycznego przekonania o niewątpliwej równości wszystkich ludzi. Narracja w obu opowieściach prowadzona jest z perspektywy „normatów” - osób, które żyją bez niepełnosprawności i traktują to jako swego rodzaju przewagę ${ }^{28}$.

\section{Zmiana perspektywy}

Jeśli teoria różnorodności byłaby fundamentem społecznego ładu, bohaterowie z niepełnosprawnościami staliby się obiektem zainteresowania, a nie litości, a dziecięcy odbiorca mógłby się z nimi utożsamiać i przejrzeć się $\mathrm{w}$ nich jak w lustrze. W perspektywie socjologii kultury poczucie przewagi „normatów” zdeterminowane jest procesem narzucania sposobu postrzegania rzeczywistości przez dominujące grupy społeczne i jako takie pozostaje wyrazem społecznej niesprawiedliwości. We współczesnym świecie można zaobserwować znaczący wzrost świadomości społecznej dotyczącej osób z niepełnosprawnościami, ale do zburzenia pozostało jeszcze wiele szkla-

${ }^{28}$ Określenie „normat” zaczerpnięte z prac R. Garland-Thomson znosi nacechowana opozycję normalność - niepełnosprawność, która zostaje zastapiona przeciwstawieniem normatywności i nienormatywności. R. Garland-Thomson, Niezwykte ciała..., s. 759. Na niefortunny charakter pierwszej opozycji zwraca uwagę też Lennard J. Davis w wywiadzie z Magdaleną Zdrodowska, Spróbujmy przez następne dwadzieścia cztery godziny nie używać stowa „norma”, „Czas Kultury” 2019, nr 4, s. 8. 
nych sufitów. Także literacki obraz osób z niepełnosprawnościami narządów ruchu wciąż nie jest wolny od stereotypów i mitów, które - jak wskazują badania Barbary Baskin i Karin Harris - wynikają po części z izolacji osób niepełnosprawnych i niewłączania ich w relacje społeczne ${ }^{29}$. W literaturze amerykańskiej obrazy niepełnosprawności bliższe realnemu życiu zaczęły się pojawiać pod koniec lat siedemdziesiątych, po części w konsekwencji regulacji prawnych z 1975 roku, które włączyły dzieci z niepełnosprawnościami w system edukacji publicznej ${ }^{30}$. W polskiej kulturze podobny przełom zaobserwować można znacznie później, na przełomie XX i XXI wieku, kiedy to w utworach literackich zaczynają pojawiać się bohaterowie, którzy cieszą się sporą niezależnością, są aktywni społecznie i uczestniczą w wydarzeniach niezwiązanych bezpośrednio z ich niepełnosprawnościa, choć sposób ich ukazania wciąż nie jest wolny od stereotypów. Wielu niepełnosprawnych bohaterów literatury najnowszej swoje ograniczenia kompensuje wybitnymi zdolnościami w różnych dziedzinach, $\mathrm{z}$ dużym upodobaniem grywając $\mathrm{w}$ szachy i ucząc się języków obcych. Rozrywki wymagające bystrości i logicznego myślenia są dowodem wybitnej inteligencji niepełnosprawnych dzieci, które uczą się celująco, często pomagając mniej bystrym koleżankom i kolegom. Majka (Uszy do góry) po wypadku nie chodziła do szkoły niemal przez rok, ale po powrocie brylowała na lekcjach polskiego, w szpitalu bowiem dużo czytała. Miała niewielkie trudności na lekcji matematyki, ale dzięki życzliwości i zaangażowaniu nauczycielki w ciagu kilku dni bez większych kłopotów udało jej się nadrobić zaległości. Tendencja ta zdaje się nasilać w literaturze dla młodzieży, kreującej niepełnosprawnych bohaterów górujących intelektualnie nad rówieśnikami. Magda z cyklu powieści Ewy Nowak ${ }^{31}$ jest erudytką i poliglotką, a Marek - bohater Stonogi Krystyny Boglar - prowadzi badania naukowe dotyczące Wysp Wielkanocnych. Tak zakrojone fabuły nieustannie udowadniają wartość i przydatność społeczną osób niepełnosprawnych, po raz kolejny obalając dawno przebrzmiałe sądy i tezy.

Teoria Rosemarie Garland-Thomson pozwala krytycznie odnieść się do stereotypów, nie pozostawia bowiem cienia wątpliwości, że wzrok gapia przykuwa materialny aspekt dziwu. Wszelkie przymioty intelektualne nie zadziwiaja, mieszczą się bowiem w usankcjonowanej konwencją społeczną

${ }^{29}$ B.H. Baskin, K. Harris, Notes from a Different Drummer: A Guide to Juvenile Fiction Portraying the Handicapped, New York 1977, s. 5-16.

${ }^{30}$ S. Gervay, Butterflies: Youth Literature as a Powerful Tool in Understanding Disability, „Disability Studies Quarterly” 2004, vol. 24, no. 1, <https://dsq-sds.org/article/view/844/1019> [dostęp: 12.06.2020].

${ }^{31}$ E. Nowak, Wszystko, tylko nie mięta, Warszawa 2002; tejże, Lawenda w chodakach, Warszawa 2004; K. Boglar, Stonoga, Warszawa 1984. 
normie. Sprzyja to również ponownej lekturze dawnych tekstów i zdemaskowaniu zawartego w nich sposobu postrzegania niepełnosprawności. Elżbietkę - główną bohaterkę powieści Jadwigi Ruth-Charlewskiej Dziewczynka spoza szyby (1964) - uprzedmiotawiają nie tylko spojrzenia, które „drażnią i bola”" (Dziewczynka..., s. 21), ale przede wszystkim działania, których staje się mimowolnym obiektem. Matka decyduje o tym, w co Elżbietka zostanie ubrana i co będzie jadła. Harcerze bez pytania zabieraja ją na spacer. Obce dziewczynki w parku niemal zmuszają do zabawy piłką. Dziewczynka nie wie, że mogłaby stanowić sama o sobie, ale próbuje odrzucić większość propozycji, czując że ich źródłem jest poczucie przewagi i że towarzyszy im spojrzenie wcale nie barokowe, ale będące wyrazem wiedzy i władzy. Ani mama, ani koleżanki nie chcą tak naprawdę poznać Elżbietki, dowiedzieć się, co czuje i czego pragnie ${ }^{32}$. Wątpliwe zreszta, czy ona sama potrafiłaby to wyrazić. Dziewczynka zyskuje głos - nie tylko prawo do wypowiedzi, ale i umiejętność jej sformułowania - dopiero po spotkaniu z byłym żołnierzem powstania warszawskiego i konfrontacji z historią radzieckiego lotnika Aleksieja Mariesjewa ${ }^{33}$. Możliwość sformułowania oczekiwań nie pomaga jej jednak w przekroczeniu roli osoby niepełnosprawnej, a tylko umożliwia heroiczną walkę $\mathrm{z}$ ograniczeniami ${ }^{34}$.

Wojenni bohaterowie są też wzorcami odwagi dla Tadka Pióry - niepełnosprawnego harcerza z powieści Seweryny Szmaglewskiej Nowy ślad Czarnych Stóp (1973), którym koledzy opiekują się dyskretnie i troskliwie, czuwając, aby się nie potknął, rezerwując dlań najwygodniejsze miejsca i strzegąc przed wszelkimi przykrościami. Harcerze z zastępu Czarnych Stóp przywykli już do tego, że do ich gromadki dołączył niepełnosprawny druh, znają też jego kolegów z ośrodka rehabilitacyjnego. Jednak zawody pływackie, podczas których mogą obserwować niepełnosprawnych rówieśników niemal rozebranych, pozbawionych nie tylko ubrań, po części ukrywających niepełnosprawności, ale też „wyzwolonych z aparatów, protez i kul" (Nowy..., s. 93), robią na nich ogromne wrażenie. Dotąd niepełnosprawni koledzy wyróżniali się tylko nienormatywną motoryka. Teraz, kiedy stoja na trampolinie, obserwacji poddane zostaja ich ciała.

${ }^{32} \mathrm{~W}$ pierwszej części powieść realizuje wspomniany już gatunek „second fiddle” books, w którym osoba z niepełnosprawnością pełni rolę katalizatora przemian innych bohaterów, w tym przypadku podwórkowego łobuziaka Witka.

${ }^{33}$ Aleksiej Mariesjew jest bohaterem Opowieści o prawdziwym człowieku Borisa Polewoja (1946), zekranizowanej w 1948 roku przez Aleksandra Stołpera.

${ }^{34}$ Proces ozdrowieńczy Elżuni został przedstawiony w sposób nieco oderwany od realności, co było charakterystyczne dla anglosaskiej prozy przełomu stuleci, a w literaturze polskiej funkcjonowało jeszcze w pierwszej połowie XX wieku. A. Dowker, The Treatment of Disability in $19^{\text {th }}$ and Early $20^{\text {th }}$ Century Children's Literature, „Disability Studies Quarterly” 2004, vol. 24, no. 1, <https://dsq-sds.org/article/view/843/1018> [dostęp: 9.06.2020]. 
Widzowie zauważają konkretne dysfunkcje, obserwują na przykład, że „lewe udo chudeusza na tle uda prawego było wątłym, chorobliwie cienkim i bezwładnym źdźbłem" (Nowy..., s. 90). Skoki do wody w wykonaniu niepełnosprawnych osób stają się metaforą życia, które wymaga odwagi, i przedstawione zostaja jako akt heroizmu. Jeden z troskliwych harcerzy patrząc na Tadka szykującego się do skoku, szepce: „dla niego to przepaśćc" i na chwilę wstrzymuje oddech, ,jakby się bał najlżejszym tchnieniem zdmuchnąć z wysokości wielu metrów to blade, bezkrwiste chucherko" $\left(\right.$ Nowy ..., s. 91) ${ }^{35}$. Scena specyficznego rozbierania z protez nie ma tu jednak wyzwolicielskiego wymiaru cripteasu. Ilustruje raczej bezbronność kalekich dzieci, pozbawionych pomocnych sprzętów ortopedycznych i boleśnie obnaża ich niepełnosprawność.

W obu tych przypadkach niepełnosprawność przedstawiona jako tragedia osobista, przyczyna mniej lub bardziej skutecznie przełamywanej bezsilności, pełni funkcję protezy narracyjnej ${ }^{36}$. Niemal zupełnie pominięto jej wymiar społeczny, dopasowując obrazy osób z niepełnosprawnościami do oczekiwań społecznych i utrwalając stereotypy. Przywołanie dwóch tylko tekstów, które powstały o kilka dekad wcześniej niż większość omawianych tu utworów pokazuje, że analiza spojrzeń, które ku osobie niepełnosprawnej kierują poszczególni bohaterowie umożliwia zrekonstruowanie wpisanego w tekst społeczny stosunku do niepełnosprawności stanowiącego odzwierciedlenie ówczesnej mentalności. Obnażenie tych mechanizmów pozwala zestawić je z obrazem funkcjonowania społeczeństwa w tekstach najnowszych i ułatwia obserwację zmian, które dokonują się w sposobie ukazywania osób z niepełnosprawnościa. Kapria Daniels - badaczka analizująca stygmatyzację niepełnosprawności w afroamerykańskiej literaturze dla dzieci - zaproponowała wykorzystanie tego mechanizmu i wprowadzenie wybranych utworów do programu nauczania, aby można było podjąć z nimi polemikę i podważyć ich wymowę $e^{37}$. Podobny model lektury - projektowanej niejako wbrew tekstowi - proponuje też Ewa Kraskowska. I choć czyni to w odniesieniu do tekstów wyrosłych z patriarchalnej kultury, a odczytywanych z perspektywy krytyki feministycznej ${ }^{38}$, nakreślony przez nią model

${ }^{35}$ Harcerze jako opiekunowie osób z niepełnosprawnościami mają dobrze ugruntowaną pozycję w polskiej literaturze dla dzieci już w dwudziestoleciu międzywojennym (Zofia Bardówna, Kulawy chłopiec. Opowieść dla młodzieży, Warszawa 1937; Władysław Buchner, Bronek kaleka, Warszawa 1933).

${ }^{36} \mathrm{O}$ narracyjnej protezie piszą m.in. D.T. Mitchell, S.L. Snyder, Narrative Prosthesis. Disability and the Dependencies of Discourse, Michigan 2000, s. 5-14.

${ }^{37}$ K. Daniels, What Teachers Never Taught And Writers Feared To Write: Disability in African American Children's Literature, „Disability Studies Quarterly” 2004, vol. 24, no. 1, <https://dsq-sds.org/article/view/842/1017> [dostęp: 9.06.2020].

${ }^{38}$ E. Kraskowska, Czytelnik jako kobieta. Wokót literatury i teorii, Poznań 2007, s. 27. 
lektury można z powodzeniem odnieść do innych demaskujących odczytań, w których obraz świata proponowany w utworze zderza się ze skalą wartości czytelnika, a ostateczna interpretacja wyrasta z napięcia między intencja odbiorcy a intencja dzieła.

Styl odbioru zakładający pewną podejrzliwość wobec tekstu i odczytywanie literatury najnowszej w kontekście lektur - jak może się zdawać dawno już przebrzmiałych, pozwala odkryć pewien zasób niepodważonych dotąd stereotypów. Jednym z nich, powiązanym ściśle z doświadczeniem gapienia się, jest sytuowanie osoby z niepełnosprawnością w oknie, przez które przygląda się życiu, za którym tak bardzo tęskni. W oknie tkwi Elżunia jednoznacznie zdefiniowana jako „dziewczynka spoza szyby”, wygląda przez nie też Majka, która w opowieści Ireny Landau Uszy do góry (2011) z rozżaleniem obserwuje spacerowiczów i przechodniów. Takie zorganizowanie przestrzeni podkreśla izolację niepełnosprawnego bohatera, oddzielonego od świata nie tylko barierami architektonicznymi, ale odizolowanego też przez ludzką mentalność i uwarunkowania społeczne sprzyjające wykluczeniu z aktywnego życia. Niepełnosprawny w oknie staje się bowiem obserwatorem ludzkich działań, a nie ich uczestnikiem.

Dla osoby siedzącej na wózku inwalidzkim, która nie może się wychylić przez okno, tego rodzaju obserwacja jest mocno utrudniona, a widok w znacznej mierze ogranicza usytuowanie otworu okiennego i szerokość zewnętrznego parapetu. Okno w przywołanych powieściach ma jednak wymiar metaforyczny - jest wyrazem ograniczeń i marzeń o wolności, które bohaterkom obu przywołanych utworów po części udaje się zrealizować. Jednak, zarówno w przypadku Elżbietki - ofiary epidemii choroby Heinego-Medina z lat pięćdziesiątych, jak i Majki - dotkniętej paraliżem w konsekwencji wypadku, aby na powrót zaistnieć w społeczeństwie, trzeba rozpoznać własne emocje i pragnienia oraz zabrać głos i dobitnie je wyrazić. Wówczas zadziwieni nadawcy barokowych spojrzeń stają się potencjalnymi odbiorcami wypowiedzi osób z niepełnosprawnościa, co stwarza sytuację sprzyjająca podjęciu dialogu oraz wpisaniu obu stron w strukturę zróżnicowanego społeczeństwa.

W nowoczesnym świecie niepełnosprawność powinna być postrzegana jako jedna z wielu cech różnicujących członków społeczeństwa. Wówczas pozostawałaby nienacechowana, istniejąca $\mathrm{w}$ oderwaniu od medycznych konotacji i byłaby rozpatrywana w perspektywie interdyscyplinarnej. W takim - utopijnie progresywnym - modelu społecznym gapiący się i obserwowani nieustannie wymienialiby się rolami, dziwiąc się sobie nawzajem i wyrażając pragnienie poznania tożsame z próbą nawiązania kontaktu. Jednak nawet w świecie niedoskonałym, w którym gapienie się przebiega jednokierunkowo, może ono stać się fundamentem relacji. Upodmiotowie- 
nie i przyparcie do muru ${ }^{39}$ pryska bowiem w obliczu nawiązanego dialogu. Elżbietka - nieszczęśliwa dziewczynka spoza szyby - wie, że „spojrzenia ludzkie drażnią i bolą" (Dziewczynka..., s. 21), a Majka z powieści Uszy do góry najchętniej schowałaby się w szafie, aby uniknaćc natarczywych gapiów (Uszy..., s. 47). Od ciekawskiego czy pełnego współczucia wzroku sąsiadów i znajomych gorszy jednak jest całkowity brak uwagi. Jedna z bohaterek książki Duże sprawy... mówi o niemiłych sąsiadach: „Oni nigdy nie patrzą na nas. Jakby nas w ogóle nie było" (Duże..., s. 167). Ignorowanie wiąże się bowiem z całkowitą negacją i odrzuceniem innego, a gapienie się to pierwszy krok do kontemplowania cudzej inności i odkrycia prawdy fundamentalnej dla międzyludzkich dialogów:

LUDZIE SA RÓŻNI - duzi i mali, grubi i chudzi, biegają szybko lub wolno, lubią jeść czekoladę albo szpinak i lubią niespodzianki, albo ich nie lubia. Ale właśnie to jest fajne w ludziach - każdy z nas jest inny" (Duże..., s. 20).

Teoria różnorodności znosi przymus podtrzymywania raz ustalonego ładu oraz podważa postrzeganie go jako jedynego, prawomocnego i pozbawionego alternatyw. W konsekwencji dowartościowania różnic prawo bytu zyskują różnorakie porządki kulturowe i estetyczne, co minimalizuje zagrożenie przemoca (nie tylko symboliczna). Literatura dla dzieci, nie pozbawiona dydaktyzmu, z jednej strony ma więc szansę kształtować świat, z drugiej pozostaje odzwierciedleniem otaczającej rzeczywistości. Interpretacja staje się pretekstem do postawienia diagnozy, dostrzeżenia mechanizmów rządzących światem i przyczynkiem do podjęcia działań na rzecz korzystnych zmian. Barokowe gapienie się skierowane w stronę dzieła literackiego stanowi wówczas narzędzie, które w zadziwieniu pozwala odsłonić nie tylko sposób konstruowania świata przedstawionego, ale również jego relację z tym, co zewnątrztekstowe. Sposób ukazywania niepełnosprawności w tekście literackim jest bowiem wypadkową idei, której podporządkowane jest dzieło, i stosunków społecznych, które w pewnym sensie zdeterminowały jego powstanie. Analiza relacji między nimi to interesujący przedmiot badań literaturoznawczych, ale też droga do zrozumienia świata, w którym żyjemy, i być może jego korekty.

\section{BIBLIOGRAFIA}

Baskin B.H., Harris K., Notes from a Different Drummer: A Guide to Juvenile Fiction Portraying the Handicapped, New York 1977.

${ }^{39}$ Ofiara barokowego gapienia się to osoba ,jednocześnie przypierana do muru i upodmiotawiana”. R. Garland-Thomson, Gapienie się..., s. 74. 
Boglar K., Stonoga, Warszawa 1984.

Bourdieu P., Passeron J.C., Reprodukcja. Elementy teorii systemu nauczania, Warszawa 1990.

Bourdieu P., Wacquant L., Zaproszenie do socjologii refleksyjnej, przeł. A. Sawisz, Warszawa 2001.

Czermińska M., Autobiograficzny trójkat: świadectwo, wyznanie i wyzwanie, Kraków 2014.

Daniels K., What Teachers Never Taught And Writers Feared To Write: Disability in African American Children's Literature, „Disability Studies Quarterly” 2004, vol. 24, no. 1, <https://dsq-sds.org/article/view/842/1017> [dostęp: 9.06.2020].

Davis L.J., The End of Normal: Identity in a Biocultural Era, Michigan 2014.

Dowker A., The Treatment of Disability in 19th and Early 20th Century Children's Literature, „Disability Studies Quarterly” 2004, vol. 24, no. 1, <https://dsq-sds.org/ article/view/843/1018> [dostęp: 9.06.2020].

Fidowicz A., Niepetnosprawność w Polskiej literaturze dla dzieci XIX wieku, „Wielogłos” 2006, 4, s. 11-126.

Foucault M., Stowa i rzeczy. Archeologia nauk humanistycznych, Gdańsk 2006.

Garland-Thomson R., Becoming Disabled, „The New York Times”, 19.08.2016, <https:// www.nytimes.com/2016/08/21/opinion/sunday/becoming-disabled.html> [dostęp 10.06.2020].

Garland-Thomson R., Extraordinary Bodies: Figuring Physical Disability in American Culture and Literature, New York 2017.

Garland-Thomson R., Gapienie się, czyli o tym, jak patrzymy i jak pokazujemy siebie innym, przeł. K. Ojrzyńska, „Czas Kultury” 2019, nr 4, s. 73-81.

Garland-Thomson R., Niezwykte ciała, przeł. N. Pamuła, „Dialog” 2019, nr 7-8, s. 752-753.

Garland-Thomson R., Staring. How we Look, New York 2009.

Garland-Thomson R., The Story of My Work: How I Became Disabled, „Disability Studies Quarterly" 2014, vol. 34, no. 2.

Gervay S., Butterflies: Youth Literature as a Powerful Tool in Understanding Disability, „Disability Studies Quarterly” 2004, vol. 24, no. 1, <https://dsq-sds.org/article/ view/844/1019> [dostęp: 12.06.2020].

Keith L., What Writes Did Next: Disability, Illness and Cure in Books in the Second Half of the $20^{\text {th }}$ Century, „Disability Studies Quarterly” 2004, vol. 24, no. 1, <https:// dsq-sds.org/article/view/845/1020> [dostęp: 10.06.2020].

Kraskowska E., Czytelnik jako kobieta. Wokót literatury i teorii, Poznań 2007.

Makaton w rozwoju osób ze złożonymi potrzebami komunikacyjnymi, red. B.B. Kaczmarek, Kraków 2014.

Mitchell D.T., Snyder S.L., Narrative Prosthesis. Disability and the Dependencies of Discourse, Michigan 2000.

Nowak E., Lawenda w chodakach, Warszawa 2004.

Nowak E., Wszystko, tylko nie mięta, Warszawa 2002.

Ojrzyńska K., Pamuła N., Nowe studia o niepetnosprawności w humanistyce. „Przegląd Kulturoznawczy" 2019, nr 3 (41), s. 373-382.

Rzeszutko-Iwan M., Kategorie wiedzy $i$ władzy w dyskursie publicznym, „Acta Universitatis Lodziensis" 2014, 21, s. 24. 
Świerkosz M., Stwarzanie niepetnosprawnego ciała. Kilka uwag o performatywnej teorii i praktykach teatralnych, „Czas Kultury” 2019, nr 4, s. 17-26.

Thomson P., Disability in Modern Children's Fiction, „Books for Keeps” 1992, no. 75, $<$ http://booksforkeeps.co.uk/printpdf/issue/75/childrens-books/articles/other-articles/ disability-in-modern-childrens-fiction> [dostęp: 9.06.2020].

Unseen Childhoods Disabled Characters in $20^{\text {th }}$-century Books for Girls, red. H.A. Aveling, London 2009.

Wolanin A., Odmieniec i jego postawy wobec świata w twórczości Doroty Terakowskiej, [w:] Wyczytać świat - międzykulturowość w literaturze dla dzieci i mtodzieży, red. B. Niesporek-Szamburska, M. Wójcik-Dudek, Katowice 2014, s. 175-183.

Zabawa K., Ryzyko spotkania z Innym - niepetnosprawny we wspótczesnej literaturze dla dzieci, [w:] Edukacja polonistyczna wobec Innego, red. A. Janus-Sitarz, Kraków 2014, s. 121-142.

Zdrodowska M., Odrzucenie protezy: performens, polityka, tożsamość, „Czas Kultury” 2019, nr 4, s. 66-71. 